\title{
The profile of the rich antagonist and the pious protagonist in Psalm 52
}

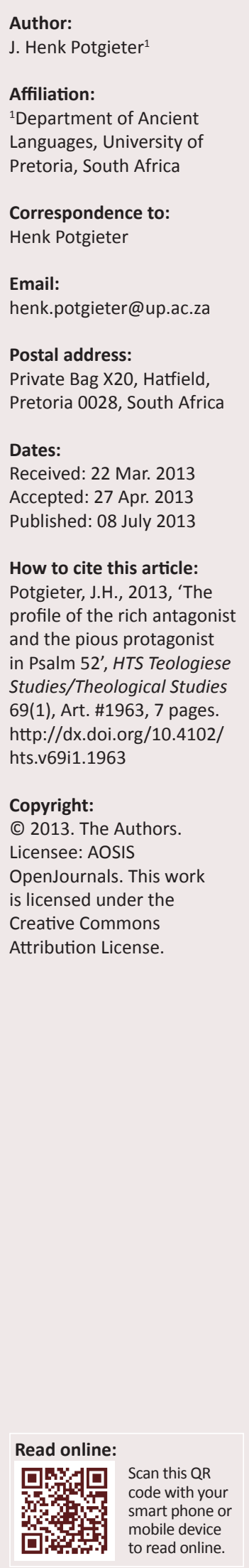

In this article, a stichometric and poetic analysis of Psalm 52 is offered which forms the basis for a description of the character of the rich but crooked antagonist and the pious protagonist in the psalm. The profile of the pious in the psalm emerges largely as the inverse of the inclination and actions of the arrogant, rich antagonist who is addressed in the greater part of the psalm. The psalm is also read and interpreted against the background of the book of Psalms as a whole to argue that Psalm 52 is actually describing the opposition between the righteous and the wicked as it is typically found in Wisdom psalms.

\section{Introduction}

This article is submitted in recognition of the giftedness and the immense contribution that James Alfred Loader made to the fields of Semitic Languages and Old Testament Science. It was written by a former student and colleague of the honorandus who at least still qualifies as a friend. I hope that it may reflect in some way the treasure of knowledge about Wisdom which Jimmie Loader has unlocked for South African students and give a glimpse of the meticulousness he has always displayed in his work.

The article ${ }^{1}$ aims to give a description of what the author or authors of Psalm 52 saw as the typical profile of an 'unbeliever' and the typical (or ideal) profile of a 'pious' person (חָסִיד). As often happens in Wisdom texts from the Hebrew Bible, the conduct and actions of 'good' and 'bad' people are contrasted in the psalm. ${ }^{2}$ In this particular psalm, the purpose seems to be to emphasise the uprightness of the implied suppliant, but the literary purpose of the text should probably be seen as an attempt to criticise the conduct of certain prominent members of society at the time of origin of the psalm and to encourage the in-group of worshippers of Yahweh to persevere in their belief that they are the righteous ones. ${ }^{3}$ What is said adversely about the antagonist and positively about the protagonist will be used in this article to draw up a profile of what the authors probably saw as the ideal of righteousness. The word חסיד, 'faithful, godly, pious', is a descriptive noun predominantly found in the Psalter where it occurs 25 of a total of 34 times in the Hebrew Bible. It is also found twice in 1 Samuel, twice in Proverbs and once in each of the books of Deuteronomy, 2 Samuel, 2 Chronicles, Jeremiah and Micah. Its presence in 1 Samuel 2:9 and 2 Samuel 22:26 - the poetic 'frame' inserted around the books of Samuel by the post-exilic Wisdom editors (in this regard, see Mathys 1994:126-157) - suggests its importance for these authors who probably used this term to distinguish themselves from the arrogant people whom they considered to be 'wicked'.4

The typical Wisdom description of the antagonist of the pious, namely a 'wicked' person (רשע), is not used in the psalm. Instead, a description of a 'mighty man' is given which seems to coincide with that of the wicked in Wisdom psalms and the book of Proverbs. The first-person speaker also does not refer to himself as a 'righteous' (צדיק) person, but the in-group is indeed referred to as both 'the righteous' (צדיקים) and the 'godly' or 'pious people' (זסידים). They obviously constitute the protagonists who stand against the evil antagonist described in the psalm as an arrogant, rich and powerful person. It therefore seems justified to inquire also about the characteristics and the profile of the group of 'pious' or 'godly' people as characterised by the psalm.

It is remarkable that the conduct of the wicked is mainly limited to descriptions from the semantic field of words describing arrogant and harmful utterances. In the first four verses of the psalm,

1.The article is part of a joint investigation with my colleague Phil Botha. I concentrated on the 'intratextual,' structural aspects of Psalm
52 whilst he focused more on the 'intertextual' intricacies in his article entitled "I am like a green olive tree": The Wisdom context of Psalm 52' (Botha 2013).

2.Such is the description of Gerald H. Wilson (2002:785) of the psalm as well: 'Like Psalm 49 and the Wisdom literature in general, the present psalm describes the contrasting lives and consequences of wicked and the righteous. As a result, whilst it is not explicitly instructive like Psalm 49, Psalm 52 does offer instructive insights by its comparison of the two ways of righteousness and wickedness.

3.I therefore regard the psalm as a late didactic Wisdom psalm rather than a pre-exilic individual lament.

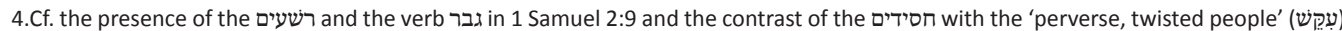
also in 2 Samuel 22:26-27. Haughtiness and impudence are characteristics singled out for criticism in 1 Samuel 2:3. 
TABLE 1: Stichometric and poetic analysis of Psalm 52.

\begin{tabular}{|c|c|c|c|}
\hline Stanza & Strophe & Hebrew & English translation \\
\hline & & 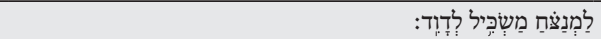 & ${ }^{1}$ For the music director; a Maskil of David \\
\hline & & 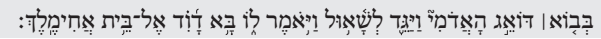 & ${ }^{2}$ when Doeg, the Edomite, came and told Saul, 'David has come to the house of Ahimelech.' \\
\hline \multirow[t]{11}{*}{1} & A & 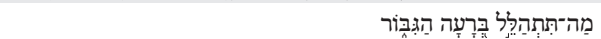 & ${ }^{3}$ Why do you boast of evil, O mighty man? \\
\hline & & חֶסֶד אֵֶל כָּל־הַיוֹםַ: & The steadfast love of God endures all day. \\
\hline & & 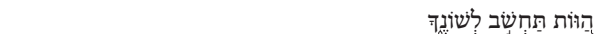 & ${ }^{4}$ Your tongue plots destruction, \\
\hline & & 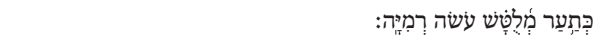 & like a sharp razor, O worker of deceit. \\
\hline & B & 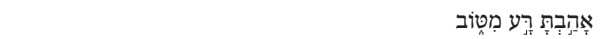 & ${ }^{5}$ You love evil and not good; \\
\hline & & 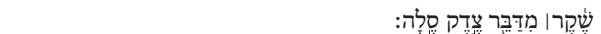 & lying and not speaking what is right. Selah. \\
\hline & & 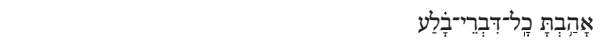 & ${ }^{6}$ You love all words that devour, \\
\hline & & לְשׁׁוֹן מְרְמָה: & O deceitful tongue. \\
\hline & C & 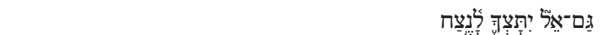 & ${ }^{7}$ But God will break you down forever; \\
\hline & & 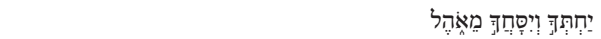 & he will snatch and tear you from your tent; \\
\hline & & 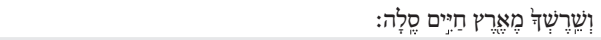 & he will uproot you from the land of the living. Selah. \\
\hline \multirow[t]{9}{*}{ II } & D & 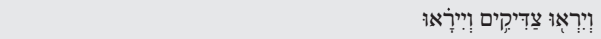 & ${ }^{8}$ The righteous shall see and fear, \\
\hline & & הִנְּה הַגֶּבֶר & 9 'See the man \\
\hline & & 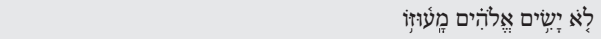 & who would not make God his refuge, \\
\hline & & 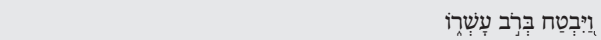 & but trusted in the abundance of his riches \\
\hline & & 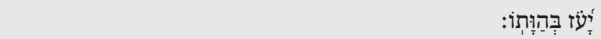 & and prevailed in his own destruction!' \\
\hline & $\mathrm{E}$ & 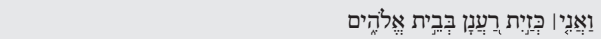 & ${ }^{10}$ But I am like a green olive tree in the house of God. \\
\hline & & 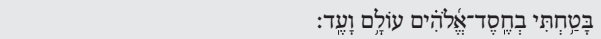 & I trust in the steadfast love of God forever and ever. \\
\hline & & 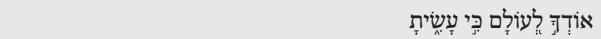 & ${ }^{11}$ I will thank you forever, because you have done it. \\
\hline & & 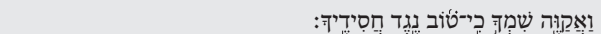 & I will wait for your name, for it is good, in the presence of the godly. \\
\hline
\end{tabular}

Note: See the discussion in Gesenius and Kautzsch for the translation of מi the sense of 'without, or separate, or free from' and 'and not' in the two stichs of this verse-line 5 (Gesenius \& Kautzsch 1978:\$119w, p. 382).

expressions like 'boasting,' 'your tongue devises mischief,' 'your tongue working deceitfully' and 'you love devouring words, you deceitful tongue' are used to describe the conduct of the wicked. The only exception occurs in verse 9 where one aspect of the emotional life of the wicked (more particularly his confidence) is described. This consists of his trusting in the abundance of his riches.

The profile which emerges of the wicked person is thus that of a wealthy individual who, because of his sound financial power-base, arrogantly thinks that he can say what he likes and use his power to dominate or intimidate other people. It is also implied that the wealth of this person has been gained through the misuse of speech. This person's speaking is not only limited to the hurting of and lying to other human beings, but it also constitutes rebellion against God. In this description of the wicked, there is a remarkable resemblance to similar descriptions in Proverbs and also to those in Wisdom palms such as Psalm 73:3-12. ${ }^{5}$

The opposite of the wicked person is the pious person, the 'chasid'. A relatively small section of the psalm deals with the pious protagonist. To be able to describe the profile of the pious person in the psalm, one must thus first take cognisance of the words and deeds of the wicked. One of the most important points of contrast of the wicked and the righteous in the psalm, as in many Wisdom psalms, concerns the trust of the righteous in God and not in his riches, himself or his own wisdom. ${ }^{6}$

5.Cf. Proverbs $3: 5$ and Proverbs 11:28. The psalm actually explicates the teaching of Proverbs 11:28: 'He who trusts in his riches will fall, but the righteous will flourish likoverbs 11:28: 'He who trusts in his riches will fall, but the righteous will flourish like a green leaf.' The psalm also reflects the situation described in Psalm 12:3-6, a
psalm which has been influenced by the book of Proverbs. For this connection, see Botha (2012:40-56).

6.For example Psalms 33:21; 37:3, 5.
Psalm 52 also displays remarkable similarities to Psalm 49 and Psalm 53. A brief comparison with these psalms located in the vicinity of Psalm 52 should provide additional information on the textual strategy of the authors of the psalm and the editors of the book.

The investigation will begin with a thorough structural analysis of the psalm since it seems that the textual strategy of the author was to demarcate the two opposing religious groups with the help of antitheses which highlight their differences. Information gleaned from a structural and semantic investigation of the psalm and the depiction of the antagonist and the group of protagonists will be used to argue that the psalm displays features typically found in post-exilic Wisdom psalms and that its time of composition should probably also be sought in the Persian period.

\section{Stichometric and poetic analysis of Psalm 52}

Psalm 52 is a very cleverly composed poem which can be segmented into five strophes (A-E) (see Table 1), which in turn form two stanzas (I-II). ${ }^{7}$ Stanza I is bound together primarily through the second person forms (directed at the impious person) which occur in all three strophes. In contrast, the wicked is never addressed directly in stanza II. Strophes $\mathrm{A}$ and B contain many similarities and form a parallel in many respects: Formally both strophes conclude in the same

7.Fokkelman (2002:62) has the same segmentation into five units, but he does not group the five strophes into stanzas. Weber (2001:238-240), in contrast, segments two stanzas (3-7 and 8-11) similar to the demarcation from demarcating any strophes. Hossfeld and Zenger (2007:61), in principle, agree with the segmentation proposed here, but they promote verses $10-11$ to the status of a separate stanza (because it constitutes the only 'I-speech' in the psalm). The analysis of Auffret (1993:3-12) was also consulted. However, he changed the text so radically for his analysis that his structural analysis could not be compared meaningfully. 
manner with the two parallel appellatives 'worker of deceit' and 'tongue of deceit.' In this way, an inclusio is created between the two strophes. Both strophes contain an instance of the word 'tongue' (לשון, 4a and 6b) and also a word for 'evil' (רעה in 3a and in 5a). The 'destruction' which the tongue 'plans' in 4a develops into 'words that devour' in 6a so that there is a development from A to B. Also, the tongue is like a 'razor or knife' in $4 \mathrm{~b}$, but it is represented in 6a as also having teeth which 'devour.' In this shift from a comparison to a metaphor, there is another Steigerung. One could justifiably ask why strophes A and B have been separated in two units. The answer is to be found in the repetition of 'love' in 5a and $6 a$, which links verses 5 and 6 but distinguishes them from verses 3 and 4, and the fact that strophe A forms a parallel to strophe B, with gradual intensification. 'Your tongue' in $4 \mathrm{a}$, which is said to plot destruction metaphorically, develops into synecdoche or personification in $6 \mathrm{~b}$ where the 'mighty man' of 3a is addressed as being a 'tongue' in $6 b$.

Strophe C still addresses the evil person, but 'God' is now the subject and the evil person the object. This tristich uses three metaphors to describe the judgement of God on the evil person: He will break him down (the verb is used elsewhere with a house, a wall or an altar as its object); He will snatch and tear him from his tent (the expression was evidently borrowed from Proverbs 2:22 which says the same, but נסח [tear down] is also used in Proverbs 15:25 to describe the tearing down of a house) and He will uproot him from the land of the living as a plant is being ripped from the soil. This plant metaphor is important since it forms an antithesis to the 'green olive tree in the house of God' in verse 10. It is as if the repetition of מfrom] in the parallel antithetic descriptions in $5 \mathrm{a}$ and $5 \mathrm{~b}$, 'you love evil and not good, and lying and not speaking what is right', is echoed in $7 \mathrm{~b}$ and $7 \mathrm{c}$, 'he will snatch and tear you from your tent; he will uproot you from the land of the living.' According to Weber (2001:239), the reference to God (אל) in 3b and 7a 'frames' the stanza as a whole. Weber (2001:239) also asserts that the repetition of sibilants and the fricatives $\pi$ and $\supset$ constitute alliteration that strengthens the idea of being torn out (cf. especially the combination of יתצך כלנצ [he will tear you out] and לנצח [forever].

Strophe D begins with wordplay (paronomasia), establishing a connection between the righteous' perceiving (יראו) the judgement of God on the wicked and their cultivation of a greater respect (ייראו) for God with a simultaneous mocking of the 'mighty man' (גבור), 3a) who is now appropriately reduced to a normal 'man' גבר (גבור), 9a). Stanza II as a whole is characterised by the reaction and attitude of the 'righteous' (8a) and the 'godly' (11b) who, as a group, encompasses the whole stanza (a ring composition). ${ }^{8}$ The stanza contains three references to God, using the term אלהים in contrast to the two references in stanza I where God is referred to as אלד אל. The wicked was warned in stanza I that the 'steadfast love of God endures all day' (3b) and that God's punishment on him would be 'forever' (7a), but the more intense word עולם (10b and 11a) is used to describe the enduring trust and gratefulness of the 8.So similarly weber (2001:239). pious suppliant in stanza II. It is further augmented with 'and ever' in 10b: 'I trust in the steadfast love of God forever and ever.' Whilst the destruction of the evil person will be 'forever' (7a), the trust of the pious suppliant and his thanksgiving will also be 'forever' (10b, 11a). Strophe D is bound together through its having the righteous as the subject (8) whose direct speech (9) is quoted as a way of enlivenment. Strophes $\mathrm{D}$ and $\mathrm{E}$ also form an antithetic parallel parallelism since the trust (בטח) of the wicked man in his abundant riches (9c) and his own greed (9d) is contrasted with the trust (בטח) of the pious speaker in the steadfast love of God (10b). The ridicule of the righteous in-group also forms a contrast to the encouraging presence of the same people when they wait for Yahweh (11b).

The whole of stanza II, however, also forms an antithesis to stanza I since the boasting (3a) of the evil person is contrasted to the grateful attitude of the pious and his willingness to wait for Yahweh (11b). As has been remarked already, the 'mighty man' of 3a is reduced to a normal human being, a 'man' (גבר) in 9a (an instance of irony) (Weber 2001:240). Similarly, the 'worker' (עשה) of deceit in 4b forms a contrast to Yahweh who effects (עשה) salvation (11a) and the 'good' (טוב) which the wicked shuns (5a) forms a contrast to the 'name' of God, which is also said to be 'good' (טוב). The repetition of the stem צדק (5, cf. צדיקים [righteous people] in 8) establishes another connecting factor. Despite the evil words and intentions of the wicked person, it is the steadfast love (חסד) of Yahweh which carries the day ( $3 \mathrm{~b}$ and 10b). ${ }^{9}$ There are only two similes in the psalm, one in each stanza, which help to enhance the contrast between the wicked and the upright (4b and 10a). Finally, the stem הוה also seems to be repeated (4a and 9b). In verse 4a it is usually interpreted as representing הַוָֹה II [threats] (cf. HALOT), ${ }^{10}$ whilst in verse $9 \mathrm{~b}$, it is understood as either

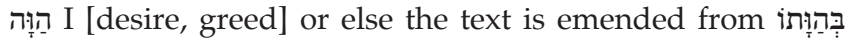
[through his desire] to parallel to עשרו [riches] in 9a, thus the suggestion in HALOT). It would seem that with about 20 words or particles being repeated in the poem itself, it was the intention of the poet to repeat the stem or to create another instance of wordplay. For that reason, the text is not emended, and the occurrence in verse 9a is interpreted as 'destruction.' Weber describes the contrast between 'boasting' of evil in 3a and 'praising' God in 11a, thus between false and right eulogising, as a frame for the whole poem (Weber 2001:240). Hossfeld and Zenger (2007:61) in turn find a brace that encloses the psalm in the חסד [steadfast love] (cf. vv. 3, 10, with the variation חסידים in 11).

As can be seen from the following diagram (Figure 1), antithesis seems to be the dominant textual strategy of Psalm 52 , a characteristic which emphasises the importance of the polarity between the wicked and the pious in the psalm.

9.Verse $3 \mathrm{~b}$ forms an antithesis with $3 \mathrm{a}$ and constitutes a declaration of trust. In form and content, it can be compared to Psalm 7:12b and Psalm 11:1. Cf. Hossfeld and Zenger (2007:60).

10. HALOT is used as an abbreviation for The Hebrew and Aramaic Lexicon of the Old Testament (Koehler \& Baumgartner 1994-2000). The references are to the words in loco. Since the electronic version was used, no page numbers are given. 


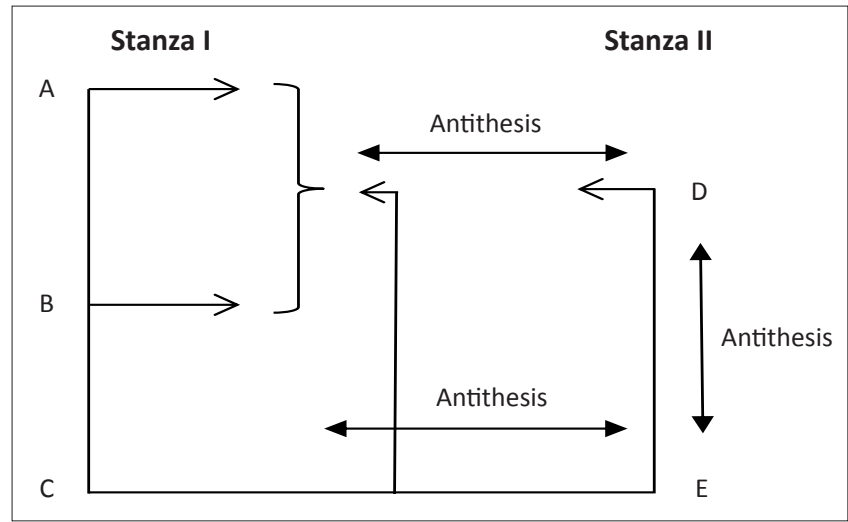

FIGURE 1: Schematic representation of the structure of Psalm 52.

\section{The profile of the impious}

Because of the structure and contents of the psalm, it is impossible to define the profile of the pious without first defining the profile of his counterpart, the 'unreligious person.' The description of the impious is found especially in the first two strophes, A and B (vv. 3-6), and then again in strophe D (vv. 8-9). His profile can be deduced in these strophes first by the way in which he is addressed and then also by the description of his conduct.

\section{The appellatives for the impious}

Four appellatives are used. They are the vocatives הגבור [O hero or mighty man], עשה רמיה [O worker of deceit], לשון מרמה [deceitful tongue] and the third person reference to הגבר מרומ [the man]. It is evident that there is a connection between the first and last and also between the two middle appellatives, a sequence that creates a chiasmus. Both הגבר and הגר and are derivatives from the stem גבר. The psalm commences by using the epithet 'O mighty man' ironically in strophe A, and the epithet is then scaled down to 'the man or the (mere) human' in strophe D. Apart from the fact that מרמה and are also both derivatives from the stem רמה, they are synonyms and part of similar constructions as well. They are in both cases the לשון and עשה anen rectum in a construct relationship where is in the construct state. Not only do the two appellatives conclude the two strophes A and B, but they also substantiate what the real meaning of 'mighty man' is. Because the 'mighty man' is actually 'a worker of deceit' and because he has a 'deceitful tongue', he is nothing but a liar; later in the psalm, he thus becomes a mere 'person' - an object of derision.

Even when the antagonist is referred to as 'the man' (הגבר), there is a measure of irony involved. In the Psalter, this epithet is usually found in a blessing formula, 'Blessed is the man who ...' Psalm 34:9 for instance says: 'Blessed is the man who takes refuge in (Yahweh).' The first half of this verse also declares: 'Oh, taste and see that Yahweh is good!' As such, it expresses the same idea as Psalm 52:11 ('I will wait for your name, for it is good') and Psalm 52:10 ('I trust in the steadfast love of God forever and ever'). The irony of the 'man' who would not make God his refuge or trust in him in Psalm 52:9 is therefore all the more poignant. Psalm 40:5 similarly seems to render the use of 'the man' in Psalm 52:9 ironical: 'Blessed is the man who makes Yahweh his trust and does not look to the arrogant or to those who rely on things that are false.' These verses serve as part of the broad allusive context which helps us to understand Psalm 52.

\section{The utterances and conduct of the impious}

So what does this 'mighty man' do? The utterances or conduct of the impious can be grouped together according to the strophes in which they occur. In strophe A, two utterances or actions are mentioned. The second action is followed by a comparison which serves to elucidate the action.

\section{He boasts of evil}

This use of the Hitpael of the verb הלל [boast] with the preposition $\underset{7}{7}$ [in] in Psalm 52:3 again seems to imply a certain amount of irony since the usual expression in the Hebrew Bible is for the faithful to 'boast' or 'glory' in Yahweh or God, often employed in a parallel construction with to 'rejoice' in God. ${ }^{11}$ So, for instance, is David said to have given Asaph and his colleagues a song of thanksgiving to Yahweh ${ }^{12}$ which contains the command to 'boast in his holy name' (התהללו בשם קדשו, 1 Chr 16:10). This verse is identical to Psalm 105:3 from where it was borrowed according to Gosse. ${ }^{13}$ The parallel stich reads: 'Let the hearts of those who seek Yahweh, rejoice.' The author of Psalm 34, a late Wisdom psalm, similarly declares in verse 3: 'My soul will boast in Yahweh (ביהוה תתהלל נפשי); let the afflicted hear and rejoice.'14 In addition to the parallel complement 'to rejoice', other parallels are 'to be vindicated'15 or 'to bless oneself in him.' ${ }^{\prime 6}$ In contrast to this, Psalm 97:7 declares that all who 'boast in idols' (המתהללים באלילים) are put to shame since all gods bow before Yahweh.

Apart from Yahweh and idols, there are only a few other things mentioned in the Hebrew Bible in which one can 'boast.' These include a man boasting of 'gifts never given' (Pr 25:14), wise people 'boasting in their wisdom' (in Jr 9:22), a mighty man (הגבור) 'boasting in his might' and a rich person 'boasting in his riches' (יתהלל עשיר בעשרור). All such boasting is discouraged in this one verse in Jeremiah. In the next verse, the instruction is given that anyone who would want to boast should boast in the fact that they understand and know Yahweh and know that he acts out of steadfast love, justice and righteousness on earth, the things in which he delights.

These two verses in Jeremiah 9:22-23 definitely seem to be significant for the understanding of Psalm 49:7 and also for understanding Psalm 52:3. In Psalm 49:7, the psalmist

11.Psalm 105:3 (=1 Chr 16:10); Isaiah 41:16; Psalm 63:12; cf. also Psalm 64:11 which speaks of 'rejoicing' in Yahweh, taking shelter in him and 'boasting' without repeating 'in Him.'

12.Cf. 1 Chronicles 16:7.

13.Cf. Gosse (2010:22)

14.Cf. also Psalm 64:11.

15.Isaiah 45:25.

16.Jeremiah 4:2. 
describes his opponents as people who trust in their wealth (הבטחים על־חילם) and 'boast in the abundance of their riches' (וברב עשרם יתהללו), using the same expression as in Jeremiah 9:22 (עשיר בעשרו אל-יתהלל) but in the plural. The verse in our psalm seems to take cognisance of both Jeremiah 9:22 and Psalm 49:7 since it asks the 'mighty man' (הגבור, cf. its occurrence in Jr 9:22) why he boasts 'in evil.' The connection with Jeremiah 9:22 and with Psalm 49:7 is found in the fact that the opponent is described later in the psalm, in Psalm 52:9, as 'the man (הגבר) who would not seek refuge in God but trusts in the abundance of his riches (ויבטח ברב עשרו) and prevail in his own destruction (יעז בהותו).

As was the case with the epithets 'mighty man' and 'the man,' the expression to 'boast of evil' thus also seems to constitute irony. The wicked antagonist of Psalm 52 is described as the dark counterpart, the exact opposite, of the righteous as it is found in other psalms.

\section{His tongue plots destruction like a sharp knife}

The second action in strophe A, that of 'plotting' (חשב), belongs in general semantic theory (cf. Louw \& Nida 1988:349) to a semantic sub-domain of 'to intend, to purpose, to plan' within the semantic domain 'to think,' 'which involves essentially the processing and manipulation of information, often leading to decision and choice.' In this instance, the information is manipulated or shaped by the tongue of the impious towards the destruction of the pious. It is done with such malicious efficiency ${ }^{18}$ that it is compared to the effects of a sharpened knife or a razor. ${ }^{19}$

The image of the wicked person who makes it his objective to חסיד מpious] through lies and calumniation calls to mind Psalm 4 where the suppliant asks in verse 3, 'O children of men, how long will my honour be shamed? (How long) will you love vain words and pursue lies?' He then warns his opponents in verse 4: 'But know that Yahweh sets apart the pious person for himself, the Lord will hear when I call to him.' Falsehood, flattering and deceptive speech are also the weapons of the arrogant (גבר) opponents of the pious (חסיד) in Psalm 12. Very often in the Psalter, the pious are represented as the ones oppressed by arrogant people who seem to be powerful with words. ${ }^{20}$

\section{The conduct of the impious in strophe B (vv. 5-6)}

The next five utterances and actions of the impious are grouped together in strophe B and seem to be the natural result of the 'planning' in strophe A. They consist of two binary pairs

17.The noun הִ plays an important role in this psalm and other psalms in its vicinity It occurs in Psalm 52:4 and Psalm 9 and also in Psalm 55:12 and Psalm 57:2. In al three psalms, the destruction is associated with dangerous words and speech cf. Psalm 55:10 and Psalm 22 (softer than butter and more soothing than oil, ye hiding war and really being drawn swords) and Psalm 57:5 (people whose teeth are spears and arrows, and whose tongue is a sharp sword).

18.See Psalm 59:8.

19.In Psalm 7:13, the same verb לטש is used for the sharpening of a sword.

20.The 'arrogant' (עשה גאוה) are also the enemies of the חסידים [righteous] in Psalm 31:23. In Psalm 32:6 and 10, it is the 'wicked' who are the opponents of the חסיד Psalm 37:28 shows proximity to Psalm 52, for the חסידים are said to be preserved 'forever' by Yahweh, whilst the 'seed of the wicked (רשידים (רשים) will be cut off.' In Psalm 'forever' by Yahweh, whilst the 'seed of the wicked (רשעים) will be cut off.' In Psalm
$43: 1$, it is the 'deceitful and unjust man' who serves as the opponent of the חסיד. and a final concluding remark. The choice that was made after the planning is first expressed in the general terms of a binary pair: 'you love evil and not good.' By using the word רע [evil], a connection is made to the רעה [wicked] in the initial statement in verse 3. Instead of 'boasting in Yahweh', as is expected of the righteous according to other psalms, the impious boasts in evil. This becomes part of an attitude or a philosophy of life to choose evil and not good. This attitude is congruent with what is said about the wicked and the opposite of what is said about Yahweh and the righteous in other psalms. The preference for evil, for instance, forms a link to the following psalm, Psalm 53, where both verse 2 and verse 4 state that 'there is none who does good.'

This preference of the wicked for evil is subsequently explained in Psalm 52 by a more specific binary pair: 'You love lying and not speaking what is right.' It is clear that the movement is from the general to the specific. The metaphoric expression, 'you love all words that devour', brings to a head what the implications of the lies of the impious are. From the contexts where the verb בלע is used, it seems that 'to swallow, to consume completely' is part of the meaning it conveys. The words of the impious destroy the life expectancy of the pious. The evil that the impious plans and in which he boasts is executed in utterances which are untrue. These lies work to the detriment of the pious to such an extent that their existence is threatened. Similar to the preference for evil, this metaphoric complex also forms a connection to Psalm 53. Those 'who work evil' are described in Psalm 53:5 as consuming the people of Yahweh 'as though they were eating bread'. The source of this metaphor is not, as Goulder (1990:71-83) thinks, military terminology but the Wisdom criticism found in Proverbs 30:14 against the generation whose teeth are like swords and whose molars are like knives to devour the poor from the earth and the needy from among the human race.'

\section{The conduct and attitude of the impious in strophe D (vv. 8-9)}

The difference between the description of the impious in this strophe and the previous strophes is twofold. Firstly, the description is given through the eyes of the righteous and is therefore done in the third person. Secondly, in contrast to the previous description, the focus is now on the attitude and conduct of the impious person and not so much on his utterances. Thus the quadruple reaction of the righteous is foregrounded; they see, they fear, they laugh and they say (the last verb is implied). The first two reactions are consequences of God's retaliation, which is described in strophe C, and the last two are aimed at the impious.

Through the intervention of God in strophe C, the roles of the impious and the pious were changed. In the first stanza (vv. 3-6), the impious person was the 'mighty man', and the pious was the object of his evil planning and his 'words that devour'. In strophe D in the second stanza, the 'mighty man' of strophe A becomes only 'the man' and is now an object of 
laughing and ridicule. Where the expression 'the man' is the subject of a formula of blessing in the other psalms, in Psalm 52 it is the object of ridicule. The ridicule is formulated by, inter alia, the same person who was the victim of his planning and evil deeds. In contrast to his 'sharp' tongue, which kills and devours with deceit, the ridicule of the righteous is only implied: Their words are quoted, but the utterance is described as 'laughing. ${ }^{21}$

Why will this happen to the impious? The answer to this question is given by the righteous. It is mainly because the wicked person made the wrong choice. Instead of making God his refuge, he trusted in the abundance of his riches. As a result of this, he prevailed in his own destruction..$^{22}$ There is coherence and connectivity between the three actions. The wrong conduct of the impious is contrasted to the right conduct of the pious. The consequence of the wrong conduct is destruction. In this antithesis between the first and second actions, the major difference between the pious and impious is illustrated. The pious trusts or takes refuge in God whilst the impious trusts (בטח) in his riches. Therefore his end will be fittingly the הוה, the 'destruction' which he planned (v. 4) for others. With this verdict the description of the impious comes to an end and nothing more is said about him. In the next verse (10), the pious is the centre of attention.

\section{The profile of the pious (חסיד צדיק or)}

Whilst the description of the impious is done either in the second or third person, the pious describes himself and his own conduct in the first person. With the foregrounding of the personal pronoun with vav adversative (ואני) with which the strophe begins, one gets the sense of a confession or a credo which will follow. The credo commences not with what he believes or does but with an image. In this image, the pious is compared to an olive tree. One must be aware of the strategy of the poet to refer backwards or forwards by using the same word or words derived from the same stems. Sometimes the referred words will have the same meaning and sometimes the meaning will differ, but a framework is created through which the profiles of the two antagonists are elucidated.

\section{'I am like a green olive tree in the house of God'}

The expression 'green olive tree' occurs only twice in the Hebrew Bible - in this psalm and in Jeremiah 11:16 - but the idea of the חָסִיד which is compared to a tree planted in the 'house of God' is worked out extensively in Ps 92:13-15 (note the same image also in Ps 1 and in Jr 17). It seems that the expression conveys the idea of vitality, prosperity and stability. This life-enhancing existence of the חָסִיד stems from the blessings of God which form an antithesis to God's punishment for the wicked in strophe C of stanza I. In fact, it is only against the backdrop of that punishment in strophe $C$ that the full extent of the expression can be grasped.

21. Such laughing is of course also a Wisdom motif since Lady Wisdom threatens to 'laugh' at the distress of those who would not follow her advice ( $\operatorname{Pr} 1: 26)$

22.See the comments of Tate in notes 9a and 9b on the translation of עוה in and הוה in this verse (Tate 1990:34).
Especially the last stich, 'he will uproot you from the land of the living' is the precise opposite of 'a green olive tree in the house of God.' The 'uprooted (dead) tree' of strophe $C$ is contrasted with the 'green (living and thriving) olive tree', and the 'house of God' is the 'land of living' par excellence. ${ }^{23}$ It is noteworthy that the image of a verdant tree is often contrasted in the Hebrew Bible with the image of the wicked as chaff being scattered by the wind or a plant that withers or is uprooted. ${ }^{24}$

\section{'I trust in the steadfast love of God forever and ever'}

Not only does this verse-line pick up the theme of the covenant love of Yahweh from verse 3, but it also stands in stark contrast to the conduct of the impious person in verse 11 who 'trusted in the abundance of his riches'. There is also a significant change regarding the wording of the theme in verse 3. Verse 3 speaks about 'the steadfast love of God which endures all day.' The 'all day' becomes 'forever and ever' in verse 11. It is not only a momentary act of the pious, which lasts for a day, but his trust in the steadfast love of God is a way of life which endures for his whole life. The phrase 'forever and ever' in this stich as well as in the next one strengthens the idea that this is actually a credo or at least part of one.

\section{'I will thank you forever, because you have done it'}

Thanksgiving or praise is an integral part of the Psalms of Praise and the Psalms of Lament, but it is also part of other literary types of the psalms as in this case. The combination

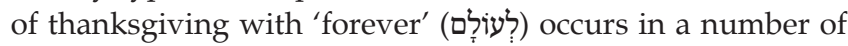
psalms, ${ }^{25}$ but taken together with the 'forever and ever' of the previous line, it accentuates the fact that thanksgiving, in contrast to what is true of the impious, is an integral part of the life of the pious person. According to Van der Ploeg (1973:327), the expression 'because you have done it' is well attested in the Old Testament ${ }^{26}$ and is a summation of everything that Yahweh did for the pious, including the punishment of the impious. So the thanksgiving of the pious is a result of the blessings which he received from God.

\section{'I will wait for your name, for it is good, in the presence of your faithful'}

Nowhere in the psalm is the impious called a רשא [wicked] and only in the last verse-line of the psalm is the pious suppliant by implication described as a חסיד. This happens when he says 'I will wait in the presence of your faithful' (חסידיך). Twenty-five per cent of the occurrences of the stem, קוה 'to await, to hope', in the Hebrew Bible is found in the Psalms. It often expresses the ideal attitude of the pious in

23.Keel (1997:123): 'The temple is a sphere of highly intensified life and blessing.' Cf. also p. 135 for the presence of trees in the courts of the temple.

24.Cf. Psalm 1:3-4; Psalm 37:2, 35-36; Psalm 92:8-16; Jeremiah 17:5-8.

25.Psalm 30:13; Psalm 79:13 and Psalm 86:12

26.Psalm 39:10; Psalm 22:32 and Isaiah 38:15 
the so-called psalms of the poor ${ }^{27}$ and is often used in the concluding verse of a psalm to express a command to 'Israel' to 'wait', similar to the idea expressed with the verb יחל יחל 'The remark in Psalm 52:11 that the speaker will also 'wait' for God therefore implies that he is also one of the חסידים.

\section{Conclusion}

As in the case in Psalm 73, the number of verses which deals with the wicked is nearly twice that of the verses dealing with the pious. In Psalm 52, the pious and his conduct are only mentioned in the last two verses of the psalm, namely verses 10 and 11. Apart from the comparison with the olive tree, only three actions of the pious are mentioned. These three - 'I trust', 'I will thank you' and 'I will wait for your name $^{\prime}$ - are all reactions to the steadfast love of God. Whilst the wicked or impious person acts out of his own volition for the purpose of his self-enrichment and to his (eventual) own detriment, the conduct of the pious is not aimed at selfglorification but emanates from his reverence for God and speaks of dependence, gratefulness, growth and blessing.

The similarities in the description of the wicked and the pious in Psalm 52 with similar descriptions found in Psalms 1, 12, 13 (=53), 37, 49, and 73, amongst others, seem to confirm the thesis of Beyerlin (1980:92) that Psalm 52 should be recognised as a paraenetic-didactic Wisdom poem from the post-exilic period. Hossfeld and Zenger (2005:29) downplay the connections with Psalm 37, stating that 'despite the many parallels in detail and in certain particular insights, the function of the cause-and-effect relationship has shifted between Psalm 37 and Psalm 52.' They also claim that Psalm 52 is very different from Psalm 49 in 'diction, style, and statement' and that, in Psalm 52, there:

... has not yet been a religious division of the community of God into evildoers and righteous, as in Psalm 73, where the evildoers stand outside the divine community of the pure of heart (cf. 73:1, 15, 28), outside the true Israel. ${ }^{29}$ (Hossfeld \& Zenger 2005:29)

Absence of evidence of such a division in Psalm 52 can, however, hardly be used to infer that it did not exist. It is true that Psalm 52 differs in style from Psalms 37, 49 and 73 since each of these Wisdom psalms has been cast in a 'Gattung' that differs from that of Psalm 52. Despite the differences, however, these psalms all display the same profile of arrogant, wicked people who put their trust in their affluence and their ability to oppress people with the help of deceit. Such similarities with Psalm 52 may be pointed out in Psalm 49:7, 13-14 and in Psalm 73:3, 6, 8-9 and 12.

27.Cf. its occurrence in Psalm 25:3, 5, and 21 ; the parallel in Psalm 37:9 and 34; and Psalm 130:5.

28.Cf. Psalms 27:14; 37:34; 130:7; 131:3.

29.For this, they make use of the investigation of Irsigler (1984:318, n. 16; 245, n. 6; 369, n. 60).
On the basis of this pronounced profile of the wicked, as well as the depiction of the uprooting of the wicked and the flourishing of the pious like plants (cf. Pss 1:3-4; 37:35-40), we have to conclude that Psalm 52 originated from approximately the same time as the known post-exilic Wisdom psalms. Also, it is similar to these post-exilic Wisdom psalms in its attempt to encourage the pious in the face of the seeming success of arrogant, wicked people. As it is the case with the Wisdom psalms, the text of Psalm 52 also suggests that Proverbs was available to its author, something which in turn strongly argues for its being composed in the time after the exile. The antithesis between the arrogant powerful man and the pious community in Psalm 52 and the ironic emphasis on the distinction demonstrate that this psalm should most probably also be considered a product of late Wisdom thinking.

\section{Acknowledgements Competing interests}

The author declares that he has no financial or personal relationship(s) which may have inappropriately influenced him in writing this article.

\section{References}

Auffret, P., 1993, 'Et moi, comme un Olivier verdoyant,' in P. Auffret (ed.), Voyez de vos yeux, Étude structurelle de vingt Psaumes, don't le psaume 119, pp. 3-12, Brill, Leiden.

Beyerlin, W., 1980, Der 52. Psalm, Studien zu seiner Einordnung, Kohlhammer, Stuttgart/ Berlin/Köln/Mainz.

Botha, P.J., 2012, 'Pride and the suffering of the poor in the Persian period: Psalm 12 in its post-exilic context,' Old Testament Essays 25(1), 40-56.

Botha P.J., 2013, “'I am like a green olive tree”: The Wisdom context of Psalm 52', HTS Teologiese Studies/Theological Studies 69(1), 8 pages. http://dx.doi.org/10.4102/ hts.v69i1.1962

Fokkelman, J.P., 2002, The Psalms in form, Deo Publishing, Leiden.

Gesenius, W. \& Kautzsch, E., 1978, Hebräische Grammatik, transl. A.E. Cowley, 2nd English edn., reprint of the 28th German edn., Oxford University Press, Oxford.

Goulder, M.D., 1990, The prayers of David: Psalms 51-72, T\&T Clark, London.

Gosse, B., 2010, David and Abraham: Persian period traditions, Gabalda, Pendé. Hossfeld, F-L. \& Zenger, E., 2005, Psalms 2: A commentary on Psalms 51-100, transl. L.M. Maloney, Minneapolis, Fortress Press.

Hossfeld, F-L. \& Zenger, E., 2007, Psalmen 51-100, Herder, Freiburg/Basel/Vienna.

Irsigler, H., 1984, Ps. 73 - Monolog eines Weisen, EOS, St. Ottilien.

Keel, O., 1997, The symbolism of the Biblical world: Ancient Near Eastern iconography and the book of Psalms, Eisenbrauns, Winona Lake. PMCid:1389259

Koehler, L. \& Baumgartner, W., 1994-2000, The Hebrew and Aramaic lexicon of the Old Testament, revised by W. Baumgartner \& J.J. Stamm, with assistance from B. Hartmann, Z. Ben-Hayyim, E.Y. Kutscher \& P. Raymond (eds.), transl. \& ed. under the supervision of M.E.J. Richardson, Koninklijke Brill, Leiden.

Louw, J.P. \& Nida, E.A. (eds.), 1988, Greek-English lexicon of the New Testament based on semantic domains, United Bible Societies, New York. PMCid:1267932

Mathys, H-P., 1994, Dichter und Beter: Theologen aus spätalttestamentlicher Zeit, Universitätsverlag, Freiburg.

Tate, M.E, 1990, Psalms 51-100, Word Books, Dallas.

Van der Ploeg, J.P.M., 1973, Psalmen deel I, Psalm 1 T/M 75, J.J. Romen \& Zonen, Roermond.

Weber, B., 2001, Werkbuch Psalmen I, Die Psalmen 1 bis 72, Kohlhammer, Stuttgart. Wilson, G.H., 2002, Psalms, vol. 1, Zondervan, Grand Rapids. 